\title{
Synthesis, spectral studies, molecular structure determination by single crystal X-ray diffraction of (E)-1-(((3-fluoro-4-morpholinophenyl)imino)methyl)napthalen-2-ol and computational studies by Austin model-1(AM1), MM2 and DFT/ B3LYP
}

\author{
Dhananjay Rao Thandra ${ }^{1} \cdot$ Rajeshwar Rao Bojja $^{2}$ [D $\cdot$ Ramachandraiah Allikayala $^{1}$
}

Received: 20 July 2020 / Accepted: 16 September 2020 / Published online: 5 October 2020

(c) Springer Nature Switzerland AG 2020

\section{Abstract}

(E)-1-(((3-fluoro-4-morpholinophenyl)imino)methyl)napthalen-2-ol (1) has been synthesized and its computational investigations have been carried out through semi-empirical Austin Model-1 (AM1), SCF-MM2 and DFT/B3LYP methods in relation to its solid state molecular structure determined by single-crystal X-ray diffraction to correlate structural parameters in the gaseous state under vacuum to empirical those of the molecule in its crystalline solid state. The compound is reported to crystallize in monoclinic system in space group P21/n with crystal data as $a=15.1589(12) \AA, b=7.4349(5)$ $\AA, c=15.4287(13) \AA, \beta=98.340(4), V=1720.5(2) \AA^{3}, Z=4$, density $=1.353 \mathrm{Mg} / \mathrm{m}^{3}, F(000)=736, T=296(2) \mathrm{K}$, obtained through reflections collected/unique $=13,631 / 4112$. The shifts in various relevant bond lengths, bond angles, dihedral angles, etc. under AM1, B3LYP and MM2 treatments are discussed.

Graphic abstract (E)-1-(((3-fluoro-4-morpholinophenyl)imino)methyl)napthalen-2-ol has been synthesized and its structural aspects in its solid state obtained by single crystal XRD have been compared with those in its gas phase evaluated by Austin Model-1 under AM1, DFT/B3LYP and ChemSoft's ChemDraw Pro under MM2 Calculations.

Electronic supplementary material The online version of this article (https://doi.org/10.1007/s42452-020-03525-0) contains supplementary material, which is available to authorized users.

Ramachandraiah Allikayala, archem@nitw.ac.in | 'Department of Chemistry, National Institute of Technology Warangal, Warangal 506004, India. ${ }^{2}$ Kakatiya Thermal Power Project (O\&M), Chelpur, Telangana State, India. 

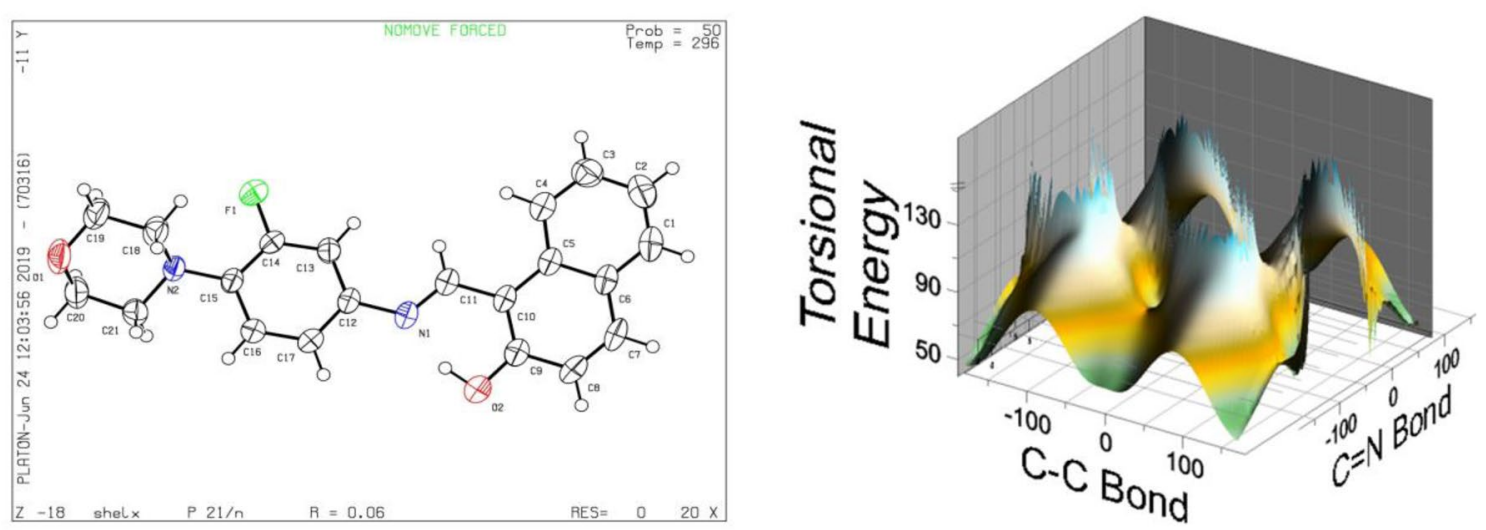

Keywords Schiff's base $\cdot$ X-ray diffractometry $\cdot$ Semi-empirical calculations · DFT calculations · Conformational analysis

\section{Introduction}

Schiff bases are known to have wide range of applications in the pharmacy, industry, electrochemistry, agriculture, etc.[1-10]. Morpholine and its phenyl substituted derivatives have been extensively utilized as antimalarial, antioxidant, antimicrobial, anti-inflammatory and analgesic properties [11-19]. The Schiff base complexes have been used in catalytic reactions $[20,21]$ and as models for biological system. Schiff bases generated with adduction of pharmaceutically useful chemical systems would be expected to offer synergic applications that can be evaluated by modern molecular modelling calculations. Austin Model-1 (AM1) is the semi-empirical method which uses Schrödinger's equation; Molecular mechanics (MM2) method is the classical mechanics which is available in ChemSoft's ChemDraw Pro with Self Consistent Field (SCF) theoretical methods to optimize stable structures to predict various properties [22-25]. However, these two methods are gradually being replaced by relatively more advance computational techniques that are based on Density Functional Theory (DFT) which includes interelectronic interactions through functionals (rather than simple electronic wave functions) in many-electron and many-atom molecular systems. One extension of this theory is by Becke-3-parameter-Lee-Yang-Parr (B3LYP) which uses hybrid functionals and marketed as Gaussian 16. Here, we present the single crystal X-ray diffraction data of a newly synthesized Schiff base, (E)-1-(((3-fluoro4-morpholinophenyl)imino)methyl)naphthalene-2-ol (1) besides some relevant molecular geometric parameters evaluated from three computational methods, viz, AM1, MM2 and DFT/B3LYP platforms, to correlate the experimental and computational data on $\mathbf{1}$.

\section{Experimental}

\subsection{Reagents and Techniques:}

All the required chemicals, viz., 2-hydroxy-1-napthaldehyde (HIMEDIA, 98\%), 3-Fluoro-4-morpholinoaniline (TCl, 98.0\%), methanol (FINAR, 99.8\%), chloroform (FINAR, 99.9\%), hydrochloric acid (FINAR, Assay 35-38\%) were of analytical grade and used as received. Whatman Grade 41 filter paper (pore size $20 \mu \mathrm{m}$ ) was used for filtration of the obtained compound. Melting points were recorded on a Stuart SMP30 melting point apparatus. UV-visible spectra were recorded using a Perkin-Elmer Model Lambda 25 UV-visible Spectrophotometer. NMR spectra $\left({ }^{1} \mathrm{H}\right.$ and ${ }^{13} \mathrm{C}$ ) were recorded on a Bruker Ascend $400\left({ }^{1} \mathrm{H}\right)$ or 100 $\left({ }^{13} \mathrm{C}\right) \mathrm{MHz}$ spectrometer. Single crystal data collections and corrections for 1 was done on a Bruker D8 Quest with CCD diffractometer under a Mo Ka $(\lambda=0.71073 \AA$ ) using a graphite monochromatic $X$-ray beam with a crystal to detector distance of $40 \mathrm{~mm}$. The structure solutions were

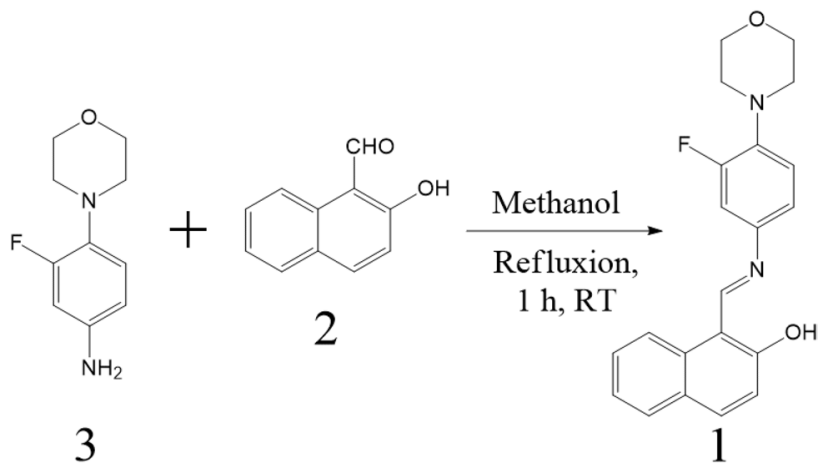

Scheme 1 Synthetic scheme of 1 
Fig. 1 XRD- ORTEP diagram of 1 with atom-numbering

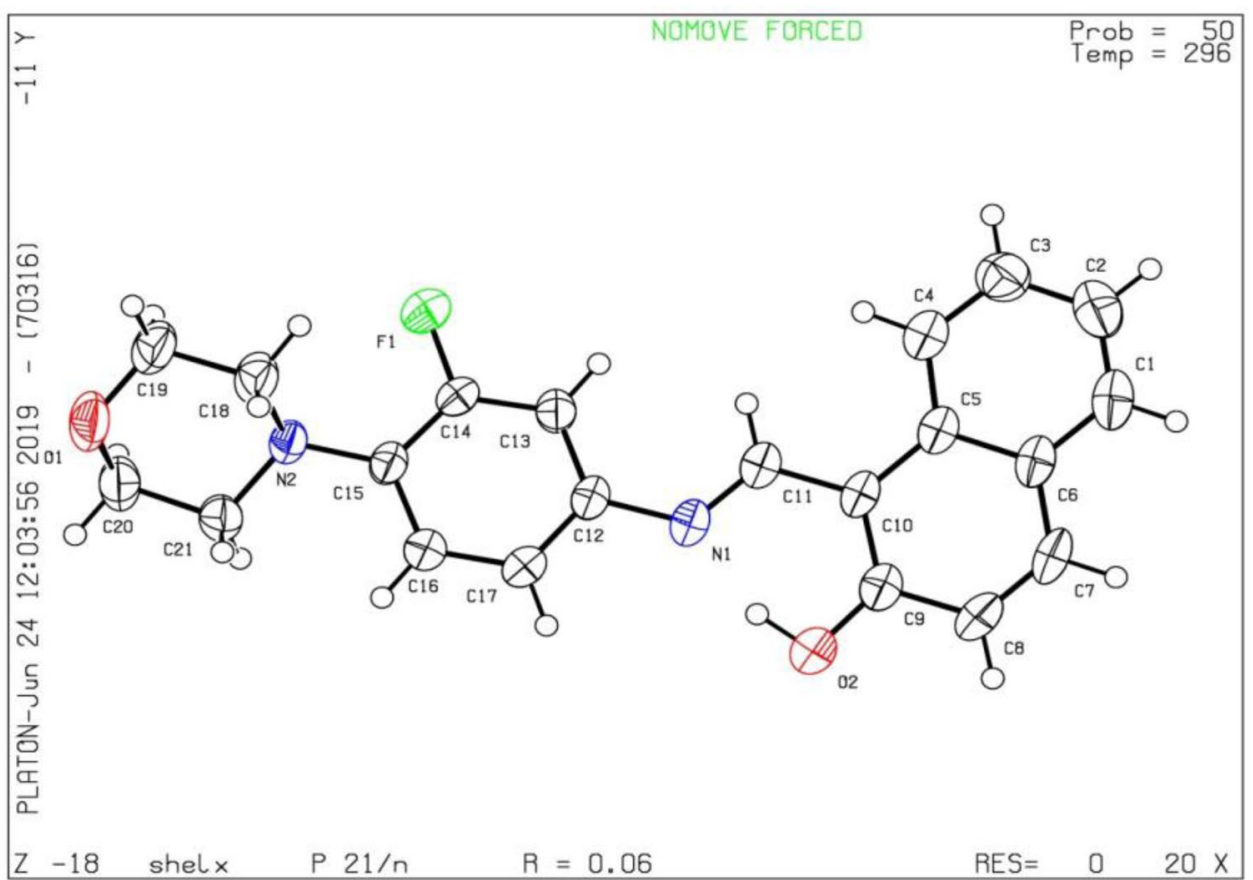

done by using SHELXS-97 and refined by full matrix least squares refinement using SHELXL-97.

\subsection{Synthesis \\ of (E)-1-(((3-fluoro-4-morpholinophenyl)imino) methyl)naphthalene-2-ol (1)}

A mixture of 2-hydroxy-1-napthaldehyde, 2, $(0.172 \mathrm{~g}$, $1 \mathrm{mM}$ ) and 3-fluoro-4-morpholinoaniline, 3, (0.196 g $1 \mathrm{mM}$ ) was dissolved in methanol and refluxed for an hour after spiked with 2 drops of $\mathbf{H C l}$ to yield an yellow colour compound, 1, (Scheme 1) which was filtered, washed several times with cold methanol and dried. Crystals were grown for this Schiff base in methanol and chloroform mixture $(1: 3 \mathrm{v} / \mathrm{v})$.

Yield: $92 \%$; M.P: $178{ }^{\circ} \mathrm{C}$; Elemental analysis (calc): C, 72.10\% (71.98); $\mathrm{H}, 5.38 \%$ (5.47); N, 7.78\% (8.00); O, 9.34\% (9.13); FT-IR (KBr), v $\left(\mathrm{cm}^{-1}\right): 3146.8 \mathrm{~m}, 2975.8 \mathrm{~m} \mathrm{(N-H)}$, $1572.1 \mathrm{~s}(\mathrm{C}=\mathrm{N}), 1488.7 \mathrm{~m}(\mathrm{C}=\mathrm{C}), 1376.6 \mathrm{~s}(\mathrm{C}-\mathrm{N}), 3450 \mathrm{br}$, $(\mathrm{O}-\mathrm{H})$; Electronic Spectral data: $315 \mathrm{~nm}\left(\mathrm{n} \rightarrow \pi^{*}\right), 424 \mathrm{~nm}$ $\left(\pi \rightarrow \pi^{*}\right)$;

\subsection{NMR spectral studies of 1:}

${ }^{1} \mathrm{H}$ NMR $\left(400 \mathrm{MHz}, \mathrm{CDCl}_{3}\right), \delta 15.37(\mathrm{~s}, 1 \mathrm{H}), 9.34(\mathrm{~s}, 1 \mathrm{H})$, $8.12(\mathrm{~d}, J=8.4 \mathrm{~Hz}, 1 \mathrm{H}), 7.81(\mathrm{~d}, J=8.8 \mathrm{~Hz}, 1 \mathrm{H}), 7.74(\mathrm{~d}$, $J=8.0 \mathrm{~Hz}, 1 \mathrm{H}), 7.53(\mathrm{t}, J=8.0 \mathrm{~Hz}, 1 \mathrm{H}), 7.35(\mathrm{t}, J=7.2 \mathrm{~Hz}$, $1 \mathrm{H}), 7.16-7.11(\mathrm{~m}, 3 \mathrm{H}), 6.99(\mathrm{t}, J=9.2 \mathrm{~Hz}, 1 \mathrm{H}), 3.89(\mathrm{t}$, $J=4.8 \mathrm{~Hz}, 4 \mathrm{H}), 3.13(\mathrm{t}, J=4.8 \mathrm{~Hz}, 4 \mathrm{H}) ;{ }^{13} \mathrm{C}$ NMR $(100 \mathrm{MHz}$,
$\left.\mathrm{CDCl}_{3}\right), \delta 167.84,154.94,141.04(\mathrm{~d}, J=9.0 \mathrm{~Hz}) 138.74$ $(J=9.0 \mathrm{~Hz}), 136.12,133.00,129.40,128.04,127.51$, $123.59,121.38,119.21,119.17,119.02,117.07,117.05$, 109.05, 108.68, 108.45, 66.96, 50.94. C, 71.98.

The imine $(-\underline{H} C=N-)$ proton, which is engaged in an intramolecular $\mathrm{H}$-bonding, gives its ${ }^{1} \mathrm{H}-\mathrm{NMR}$ chemical shift value at $15.37 \mathrm{ppm}$ (a singlet) which is slightly higher than that of a non-H-bonded imine proton. This down field shift is due to its $\mathrm{H}$-bonding to the phenolic electronegative oxygen. Conversely, the $\delta$ value of phenolic hydrogen ( $\mathrm{H}-\mathrm{O}-\mathrm{Ar}$ ) appears at $9.34 \mathrm{ppm}(\mathrm{a}$ singlet) which is slightly lower than that expected for a free phenolic hydrogen due to partial siphoning of the electron cloud on oxygen towards the imine proton through the intramolecular $\mathrm{H}$-bonding [26]. The two chemically distinguishable sets of the eight morpholine ring protons give their two triplets at $3.89 \mathrm{ppm}$ $\left(-\mathrm{C}_{2}-\mathrm{O}-\right)$ and $3.13 \mathrm{ppm}\left(\mathrm{C}_{2}-\mathrm{N}-\right)$ as expected. The $\delta$ values of the aromatic protons appear in the usual range of 6.99-8.12 ppm.

The spin-decoupled ${ }^{13} \mathrm{C}-\mathrm{NMR}$ spectral line of the phenolic carbon $(-\underline{\mathrm{C}}-\mathrm{OH})$ appears at $167.84 \mathrm{ppm}$ whereas the fluorine atom-connected carbon gives its peak at $141.04 \mathrm{ppm}$. All the other remaining aromatic carbon atoms appear in the range of 108.45-136.12 ppm. The imine carbon's $(-\underline{\mathrm{CH}}=\mathrm{N}-)$ peak appears at $154.94 \mathrm{ppm}$ while the carbon atoms of the morpholine ring show two peaks in the aliphatic region, at $50.92 \mathrm{ppm}\left(-\mathrm{CH}_{2}-\mathrm{N}-\right)$ and at $66.96 \mathrm{ppm}\left(-\mathrm{CH}_{2}-\mathrm{O}-\right)$. 
Table 1 X-ray crystallographic data for (E)-1-(((3-fluoro-4-morpholinophenyl)imino) methyl) naphthalene-2-ol

\begin{tabular}{|c|c|}
\hline CCDC & 2001213 \\
\hline Empirical formula & $\mathrm{C}_{21} \mathrm{H}_{19} \mathrm{FN}_{2} \mathrm{O}_{2}$ \\
\hline Formula weight & 350.38 \\
\hline Colour/shape & Yellow/needle \\
\hline Crystal size, $\mathrm{mm}^{3}$ & $0.6 \times 0.3 \times 0.3$ \\
\hline Temperature, $\mathrm{K}$ & $296(2)$ \\
\hline Crystal system & $\mathrm{P} 21 / \mathrm{n}$ \\
\hline Space group & Monoclinic \\
\hline \multirow[t]{4}{*}{ Unit cell dimensions, $\AA$} & $a=15.1589(12)$ \\
\hline & $b=7.4349(5)$ \\
\hline & $c=15.4287(13)$ \\
\hline & $\beta=98.340(4)$ \\
\hline Volume, $\AA^{3}$ & $1720.5(2)$ \\
\hline Z & 4 \\
\hline Density, $\mathrm{Mg} / \mathrm{m}^{3}$ & 1.353 \\
\hline Absorption coefficient, $\mathrm{mm}^{-1}$ & 0.095 \\
\hline Reflections collected/unique & $13631 / 4112$ \\
\hline$\theta$ range for data collections & $1.760-28.340^{\circ}$ \\
\hline$F(000)$ & 736 \\
\hline \multirow[t]{3}{*}{ Limiting indices } & $-19 \leq \mathrm{h} \leq 20$ \\
\hline & $-9 \leq k \leq 9$ \\
\hline & $-20 \leq \mathrm{I} \leq 20$ \\
\hline Completeness & $100.0 \%$ \\
\hline Goodness-of-fit on $\mathrm{F}^{2}$ & 1.008 \\
\hline Final $R$ indices $[I>2 \sigma(1)]$ & $\mathrm{R}_{1}=0.0564, w \mathrm{R}_{2}=0.1601$ \\
\hline R indices (all data) & $\mathrm{R}_{1}=0.1170, \mathrm{wR}_{2}=0.2123$ \\
\hline Largest diff. peak and hole $\left(\mathrm{e} \AA^{-3}\right)$ & 0.525 and -0.229 \\
\hline
\end{tabular}

\section{Results \& Discussion}

\subsection{X-ray crystal structure of 1:}

The ORTEP diagram of 1 is shown in Fig. 1 and its relevant XRD data are given in Table 1 . The reflection angle vs intensity graph is presented supplemented in Figure S5. It is found that $\mathbf{1}$ crystallizes in the P21/n space group. In Fig. 2 is shown the unit cell obtained from the single crystal X-ray diffraction studies. A close observation of the intermolecular arrangement of the 4 molecules reveals that the molecules are stacked in layers constituted by a number of possible intermolecular interactions $[27,28]$. The primary interactions seem to be weak $\pi-\pi$ interactions between any pair of adjacent molecules with one pair in a naphthalene-naphthalene stacking and another pair in naphthalene-benzene stacking while any adjacent pair inter alia being in an inverse disposition.

\subsection{Computational methods}

The structures of multi-atom, multi-ring organic molecules in solid state and gaseous state differ mostly in the bond angles and dihedral angles close to the locations of the intermolecular packing interactions $[29,30]$. To understand these aspects, a semi-empirical molecular orbital calculations were performed using Austin Model-1 (AM1), MM2 and DFT/B3LYP platforms.

The initial molecular geometry was adopted as Pople's standard data [31] and subsequently by using fully optimized energy gradient method. The conformations were
Fig. 2 Crystal packing diagram of compound 1 showing the two dimensional layer structure with $\mathrm{O}-\mathrm{H}$...N intra molecular hydrogen bonding

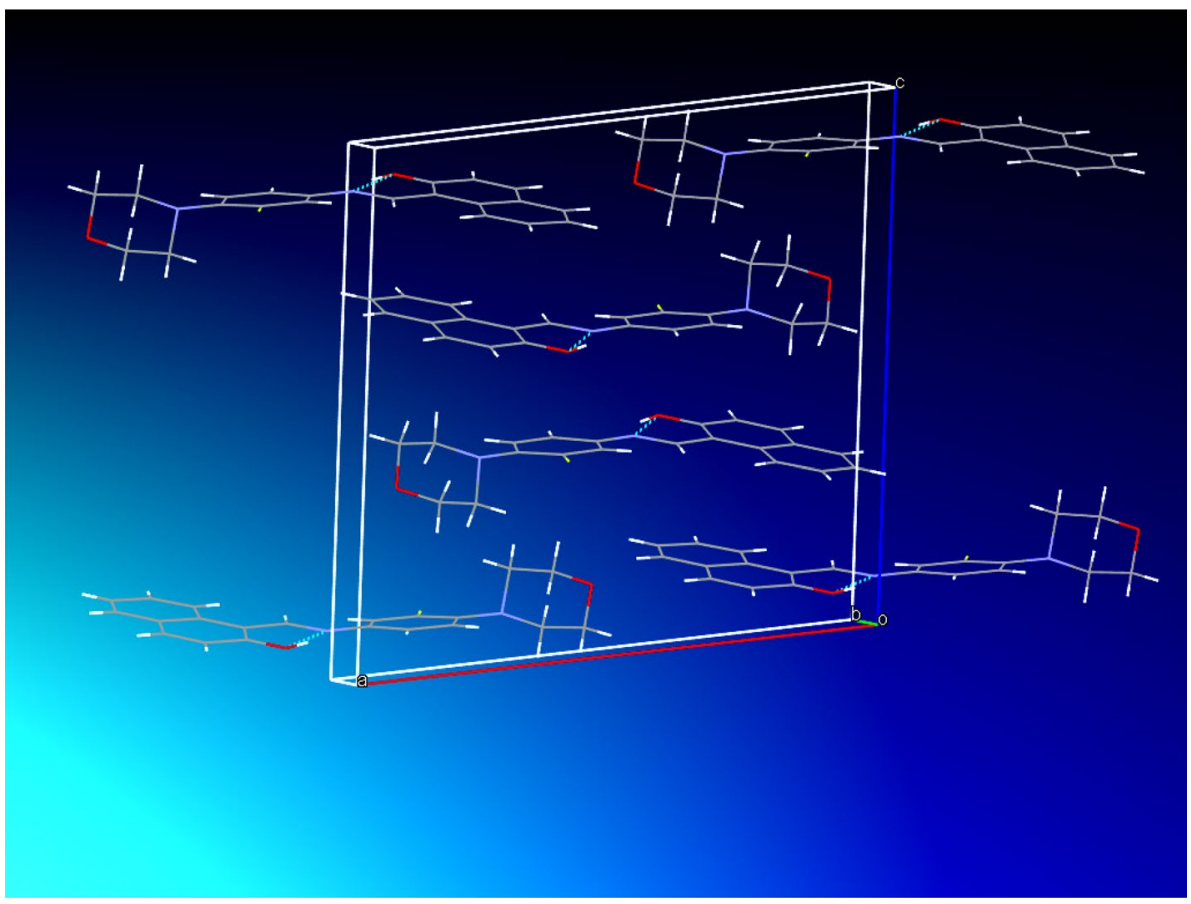


designated by Klyne-Prelog terms [32, 33] using $s=$ syn, $a=$ anti, $c=$ clinal $\left(0 \pm 30^{\circ}\right.$ and $\left.180 \pm 30^{\circ}\right)$ and all other angles $p=$ peri-planar. Conformational analysis of isolated molecule was done in the way for conformational flexible compounds [34]. Initial X-ray structures for the molecule was used for conformational analysis and the most stable conformer was energy minimized using semi-empirical AM1, MM2 and DFT/B3LYP calculations. Geometry optimizations of the crystal structure of the title compound were carried out using the Fletcher-Powell-Davidson algorithm implemented in the package and the PRECISE option to improve the convergence criteria $[35,36]$. The correlation data of various molecular parameters obtained by empirical XRD and semi-empirical AM1, MM2 and DFT/B3LYP calculations are collected in Table 2. The DFT/B3LYP with the 6-31G* basis set calculations were obtained from Gaussian 16 platform whereas molecular mechanics (MM2) were by ChemSoft's ChemOffice Pro (version 12) and the semi-empirical method (AM1 method) by Austin Model-1. The stereographic projection of the molecule after energyminimization through MM2 on ChemDraw Pro platform is shown in Fig. 3.

An interesting aspect is found here. In order to avoid steric hindrance and presumably to retain the aromaticity of each of the two aromatic rings, viz., naphthalene and benzene, the molecule is expected to have a finite dihedral angle (close to $90^{\circ}$ ) over the $=\mathrm{N}-\mathrm{C}-$ bond location, if not over $\mathrm{C}-\mathrm{CN}$ (to facilitate hydrogen bond, $\mathrm{N}$......H-O-). However, the modeling by AM1, DFT/B3LYP and ChemDraw Pro (MM2) on 1 shows near planarity of the molecule from naphthalene ring till the nitrogen of the morpholine. Relevant dihedral angles over some pertinent moieties are shown in Fig. 3 from which it is clear that the stable gas phase molecule is planar till the morpholene nitrogen. Conformational torsional energy analysis over the $\mathrm{C}$ (Naphthyl)- $\mathrm{CH}$ (azomethine) and $\mathrm{N}$ (azomethyne)$C$ (benzene) done by ChemDraw are shown in Figs. 5 and 6 respectively. Whereas the global minima represent the energy-minimized molecule (Fig. 3) with dihedral angles

Table 2 Important thermochemical and molecular energy data evaluated by AM1 and B3LYP calculations on 1

\begin{tabular}{lll}
\hline Parameter & AM1 value & B3LYP \\
\hline$E_{\text {HOMO }}(e V)$ & -8.3483 & -7.8665 \\
$E_{\mathrm{LUMO}}(\mathrm{eV})$ & -0.7490 & -1.8005 \\
$\mathrm{I}(\mathrm{eV})$ & 8.3483 & 7.8665 \\
$\mathrm{~A}(\mathrm{eV})$ & 0.7490 & 1.8005 \\
$\eta(\mathrm{eV})$ & 3.7996 & 3.003 \\
$\mu(\mathrm{eV})$ & 4.5486 & 4.8335 \\
$\chi(\mathrm{eV})$ & -4.5486 & -4.8335 \\
$\mathrm{~S}\left(\mathrm{eV}{ }^{-1}\right)$ & 0.1315 & 0.1665 \\
\hline
\end{tabular}
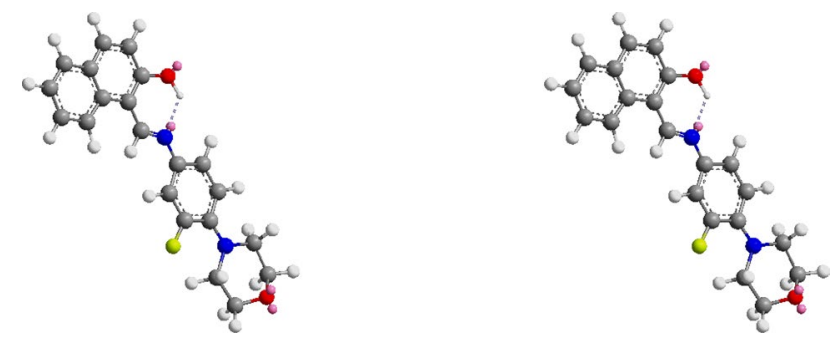

Fig. 3 Stereographic projection of MM2-energy-minimised 1 obtained from ChemDraw Pro

mentioned in Fig. 4, the local minima and global maxima are related to the dihedral angles shown in the respective Figs. 5 and 6. Since MM2 calculations take Huckel's aromaticity also, the additional stability, despite planarity, is understood on the basis of the number of $\pi$-bonds in conjugation, viz., 5 (naphthalene) +1 (azomethyne) +3 (benzene) $=9$. The number of $\pi$ electrons in conjugation become 18 which follows the Huckel's $4 n+2$ rule with $\mathrm{n}=4$. In Fig. 5 is shown, the local minimum with naphtholic oxygen and azomethine's nitrogen in an anti-geometric posture with no possibility of hydrogen bond and with a dihedral angle of about $9.5^{\circ}$ (due to steric hindrance from the oxygen's lone pair of electrons or the napholic proton and the hydrogen of the azomethine moiety, $-\mathrm{CH}=\mathrm{N}-$ ). From this diagram one can evaluate the hydrogen bond energy as about $10 \mathrm{kcal} \mathrm{mol}^{-1}$ (Difference between Global Minimum and Local Minimum). The Double Dihedral Torsional Energy Conformational Analysis over the C(Naphth)$\mathrm{CH}=\mathrm{N}-\mathrm{C}$ performed by GoldenSoft's Surfer mathematical gridding is shown in Fig. 7 which indicates higher energies when rings cross and when the system has dihedral angles close to $90^{\circ}$ and minima with planarity with rings not crossing.

Although, the preferred conformation in the solid phase can be different from that in its dilute solution and in gas
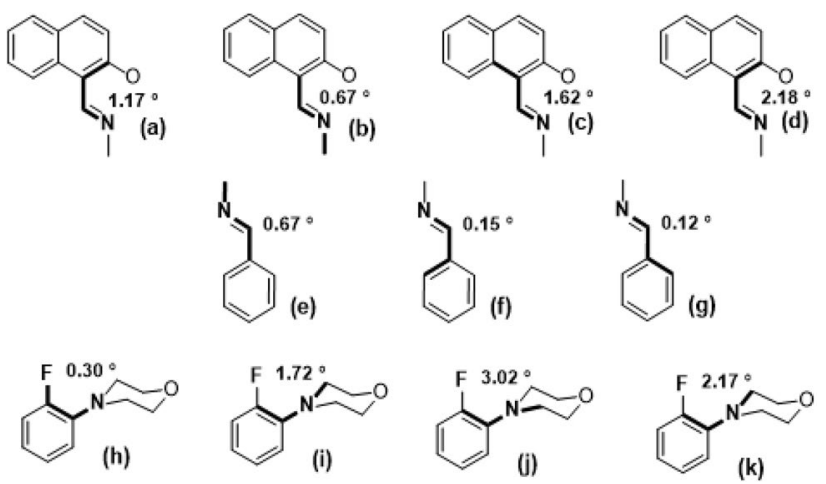

Fig. 4 Dihedral angles over various locations of energy-minimized 1 (as in Fig. 3) 


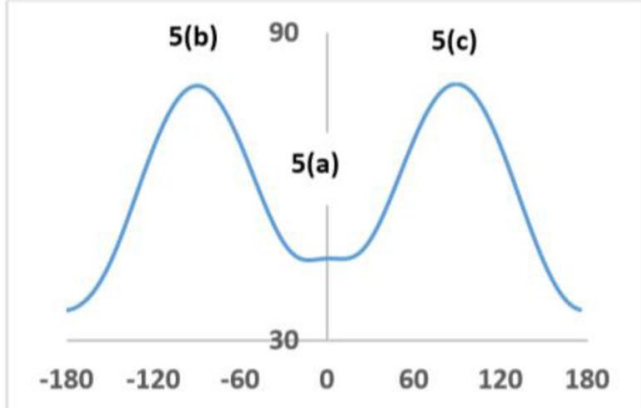

Fig. 5 Conformational Analysis over C-C Bond, shown<smiles>CN=Cc1c(O)ccc2ccccc12</smiles>

(a)<smiles>CN=Cc1c(O)ccc2ccccc12</smiles>

(b)<smiles>N=Cc1c(O)ccc2ccccc12</smiles>

(c)
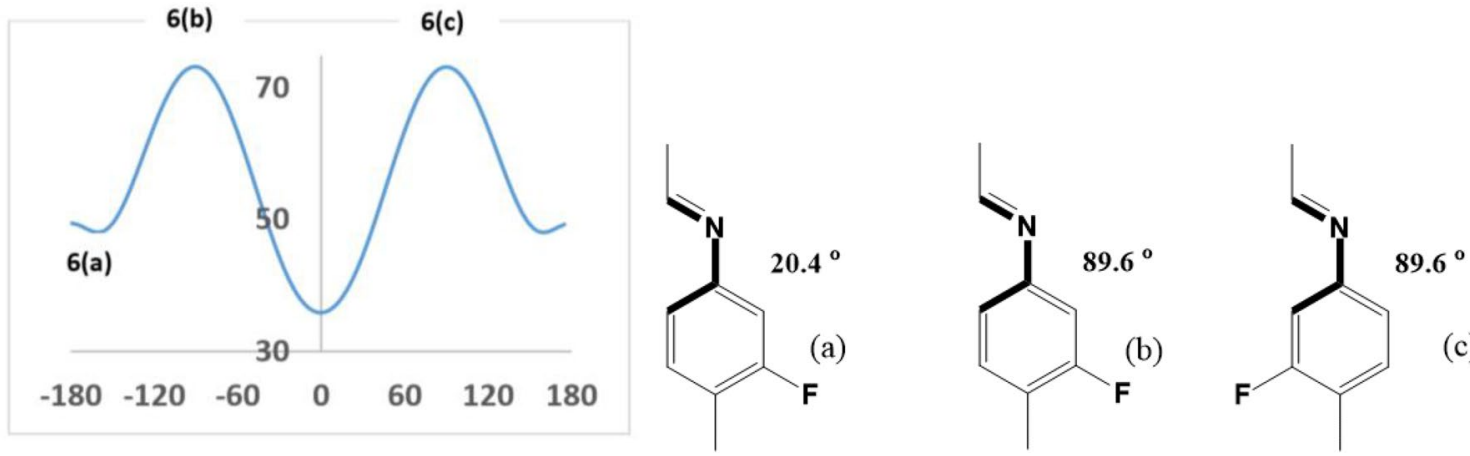

Fig. 6 Conformrational Analysis over N-C Bond, shown
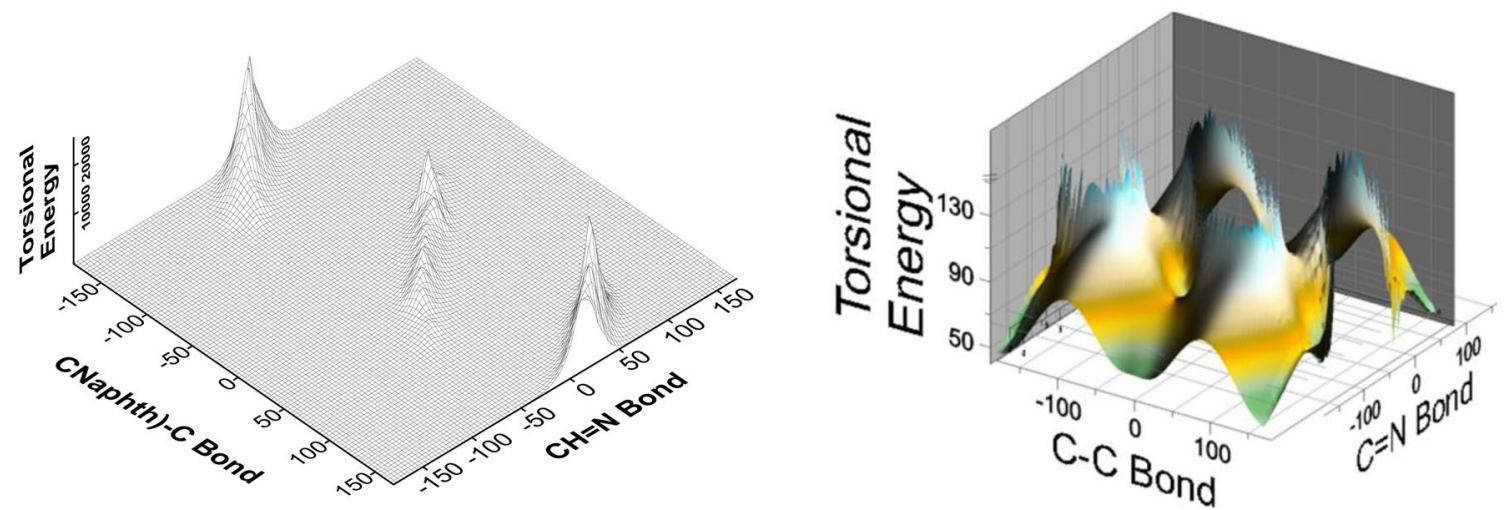

Fig. 7 Double Angle Torsional Energy Plot Over $-\mathrm{C}($ Naphth)-C=N- Moiety of 1. Full z-scale (left, wireframe) and truncated z-scale (right, surface)

phase, the X-ray diffraction data are used for comparative purpose. Overall, the combination of experimental and computational results can help in understanding the physical and chemical properties of this molecule in its condensed and gaseous states.

Some small deviations are observed between X-ray diffraction data in the solid state and computational data in the gaseous state under vacuum. The geometrical parameters are incorporated in Table 3 (bond lengths), Table 4 (bond angles) and the dihedral angles or torsion angles in Table 5. These results can be applied as ground work for prediction and exploring the other properties of the molecule (1). The numbering system of AM1 method is indicated in Fig. 3. 
Table 3 Comparative list of selected bond lengths $(\AA)$ between experimental XRD and AM1, MM2 and B3LYP Calculations

\begin{tabular}{|c|c|c|c|c|c|c|c|c|c|}
\hline \multirow[t]{2}{*}{ Bond Type } & \multirow[t]{2}{*}{ Bond Location } & \multirow[t]{2}{*}{ Bond (Fig. 8) } & \multicolumn{4}{|c|}{ Bond Lengths $(\AA ̊)$} & \multicolumn{3}{|c|}{ Variation, $\delta,(\AA)^{*}$} \\
\hline & & & $\mathrm{XRD}$ & B3LYP & AM1 & MM2 & $\Delta(\mathrm{XRD}-\mathrm{B} 3 \mathrm{LYP})$ & $\Delta(\mathrm{XRD}-\mathrm{AM} 1)$ & $\Delta(\mathrm{XRD}-\mathrm{MM} 2)$ \\
\hline \multirow[t]{10}{*}{$\sigma \mathrm{H}-\mathrm{C}\left(\mathbf{s p}^{2}\right)$} & \multirow[t]{10}{*}{ Aromatic } & $\mathrm{H}_{26}-\mathrm{C}_{1}$ & 0.930 & 1.084 & 1.099 & 1.099 & -0.154 & -0.169 & -0.169 \\
\hline & & $\mathrm{H}_{27}-\mathrm{C}_{2}$ & 0.930 & 1.086 & 1.100 & 1.104 & -0.156 & -0.170 & -0.174 \\
\hline & & $\mathrm{H}_{28}-\mathrm{C}_{3}$ & 0.930 & 1.086 & 1.099 & 1.103 & -0.156 & -0.169 & -0.173 \\
\hline & & $\mathrm{H}_{29}-\mathrm{C}_{4}$ & 0.930 & 1.087 & 1.101 & 1.104 & -0.157 & -0.171 & -0.174 \\
\hline & & $\mathrm{H}_{30}-\mathrm{C}_{7}$ & 0.930 & 1.087 & 1.101 & 1.104 & -0.157 & -0.171 & -0.174 \\
\hline & & $\mathrm{H}_{31}-\mathrm{C}_{9}$ & 0.930 & 1.085 & 1.099 & 1.104 & -0.155 & -0.169 & -0.174 \\
\hline & & $\mathrm{H}_{32}-\mathrm{C}_{15}$ & 0.930 & 1.085 & 1.102 & 1.106 & -0.155 & -0.172 & -0.176 \\
\hline & & $\mathrm{H}_{33}-\mathrm{C}_{16}$ & 0.930 & 1.084 & 1.102 & 1.102 & -0.154 & -0.172 & -0.172 \\
\hline & & $\mathrm{H}_{35}-\mathrm{C}_{19}$ & 0.930 & 1.083 & 1.102 & 1.101 & -0.153 & -0.172 & -0.171 \\
\hline & & $\mathrm{H}_{44}-\mathrm{C}_{11}$ & 0.930 & 1.092 & 1.116 & 1.093 & -0.162 & -0.186 & -0.163 \\
\hline \multirow[t]{8}{*}{$\sigma \mathrm{H}-\mathrm{C}\left(\mathbf{s p}^{3}\right)$} & \multirow[t]{10}{*}{ Alkenyl } & $\mathrm{H}_{36}-\mathrm{C}_{25}$ & 0.970 & 1.102 & 1.121 & 1.115 & -0.132 & -0.151 & -0.145 \\
\hline & & $\mathrm{H}_{37}-\mathrm{C}_{25}$ & 0.970 & 1.093 & 1.122 & 1.115 & -0.123 & -0.152 & -0.145 \\
\hline & & $\mathrm{H}_{38}-\mathrm{C}_{21}$ & 0.970 & 1.100 & 1.129 & 1.118 & -0.130 & -0.159 & -0.148 \\
\hline & & $\mathrm{H}_{39}-\mathrm{C}_{21}$ & 0.970 & 1.091 & 1.123 & 1.117 & -0.121 & -0.153 & -0.147 \\
\hline & & $\mathrm{H}_{40}-\mathrm{C}_{22}$ & 0.970 & 1.090 & 1.124 & 1.116 & -0.120 & -0.154 & -0.146 \\
\hline & & $\mathrm{H}_{41}-\mathrm{C}_{22}$ & 0.970 & 1.097 & 1.127 & 1.118 & -0.127 & -0.157 & -0.148 \\
\hline & & $\mathrm{H}_{42}-\mathrm{C}_{23}$ & 0.970 & 1.103 & 1.121 & 1.115 & -0.133 & -0.151 & -0.145 \\
\hline & & $\mathrm{H}_{43}-\mathrm{C}_{23}$ & 0.970 & 1.093 & 1.122 & 1.115 & -0.123 & -0.152 & -0.145 \\
\hline$\sigma \mathrm{H}-\mathrm{O}\left(\mathbf{s p}^{3}\right)$ & & $\mathrm{H}_{45}-\mathrm{O}_{12}$ & 0.820 & 1.007 & 0.968 & 0.966 & -0.187 & -0.148 & -0.146 \\
\hline$\sigma F-C\left(\mathbf{s p}^{2}\right)$ & & $\mathrm{F}_{34}-\mathrm{C}_{17}$ & 1.360 & 1.356 & 1.357 & 1.325 & +0.004 & +0.003 & +0.035 \\
\hline \multirow[t]{2}{*}{$N\left(\mathbf{s} \mathbf{p}^{2}\right)-C\left(\mathbf{s} \mathbf{p}^{2}\right)$} & \multirow[t]{2}{*}{ Imine } & $\mathrm{N}_{13}-\mathrm{C}_{11}$ & 1.285 & 1.298 & 1.290 & 1.266 & -0.013 & -0.005 & +0.019 \\
\hline & & $\mathrm{C}_{14}-\mathrm{N}_{13}$ & 1.417 & 1.403 & 1.412 & 1.269 & +0.014 & +0.005 & +0.148 \\
\hline$\sigma N\left(\mathbf{s} \mathbf{p}^{3}\right)-C\left(\mathbf{s} \mathbf{p}^{2}\right)$ & & $\mathrm{N}_{20}-\mathrm{C}_{18}$ & 1.412 & 1.411 & 1.419 & 1.286 & +0.001 & -0.007 & +0.126 \\
\hline \multirow[t]{2}{*}{$\sigma C\left(\mathbf{s p}^{\mathbf{3}}\right)-\mathrm{N}\left(\mathbf{s p}^{\mathbf{3}}\right)$} & \multirow[t]{7}{*}{ Aliphatic } & $\mathrm{C}_{21}-\mathrm{N}_{20}$ & 1.458 & 1.463 & 1.454 & 1.490 & -0.005 & +0.004 & -0.032 \\
\hline & & $\mathrm{C}_{22}-\mathrm{N}_{20}$ & 1.453 & 1.464 & 1.458 & 1.486 & -0.011 & -0.005 & -0.033 \\
\hline$\sigma C\left(\mathbf{s p}^{\mathbf{2}}\right)-O\left(\mathbf{s p}^{\mathbf{3}}\right)$ & & $\mathrm{O}_{12}-\mathrm{C}_{10}$ & 1.317 & 1.335 & 1.377 & 1.365 & -0.018 & -0.060 & -0.048 \\
\hline \multirow[t]{2}{*}{$\sigma C\left(\mathbf{s} \mathbf{p}^{3}\right)-O\left(\mathbf{s} \mathbf{p}^{3}\right)$} & & $\mathrm{O}_{24}-\mathrm{C}_{23}$ & 1.409 & 1.426 & 1.424 & 1.402 & -0.017 & -0.015 & +0.007 \\
\hline & & $\mathrm{C}_{25}-\mathrm{O}_{24}$ & 1.403 & 1.417 & 1.423 & 1.402 & -0.014 & -0.020 & +0.001 \\
\hline$\sigma C\left(\mathbf{s p}^{\mathbf{3}}\right)-C\left(\mathbf{s} \mathbf{p}^{\mathbf{3}}\right)$ & & $C_{22}-C_{23}$ & 1.496 & 1.551 & 1.533 & 1.529 & -0.055 & -0.037 & -0.033 \\
\hline$\sigma C\left(\mathbf{s p}^{2}\right)-C\left(\mathbf{s p}^{2}\right.$ & & $C_{11}-C_{8}$ & 1.437 & 1.446 & 1.471 & 1.356 & -0.009 & -0.034 & +0.081 \\
\hline \multirow[t]{14}{*}{$C\left(\mathbf{s p}^{\mathbf{2}}\right)-C\left(\mathbf{s} \mathbf{p}^{\mathbf{2}}\right)$} & \multirow[t]{14}{*}{ Aromatic } & $C_{2}-C_{1}$ & 1.360 & 1.380 & 1.374 & 1.342 & -0.02 & -0.014 & +0.018 \\
\hline & & $C_{3}-C_{2}$ & 1.394 & 1.410 & 1.414 & 1.337 & -0.016 & -0.020 & +0.057 \\
\hline & & $C_{4}-C_{3}$ & 1.355 & 1.377 & 1.372 & 1.338 & -0.022 & -0.017 & +0.017 \\
\hline & & $C_{5}-C_{4}$ & 1.399 & 1.416 & 1.422 & 1.347 & -0.017 & -0.023 & +0.052 \\
\hline & & $C_{6}-C_{5}$ & 1.421 & 1.432 & 1.422 & 1.354 & -0.011 & -0.001 & +0.067 \\
\hline & & $C_{7}-C_{5}$ & 1.414 & 1.424 & 1.421 & 1.341 & -0.01 & -0.007 & +0.073 \\
\hline & & $C_{8}-C_{6}$ & 1.427 & 1.448 & 1.426 & 1.364 & -0.021 & +0.001 & +0.063 \\
\hline & & $C_{9}-C_{7}$ & 1.342 & 1.367 & 1.369 & 1.335 & -0.025 & -0.027 & +0.007 \\
\hline & & $C_{10}-C_{8}$ & 1.401 & 1.413 & 1.393 & 1.358 & -0.012 & +0.008 & +0.043 \\
\hline & & $C_{15}-C_{14}$ & 1.379 & 1.402 & 1.412 & 1.344 & -0.023 & -0.033 & +0.035 \\
\hline & & $C_{16}-C_{14}$ & 1.388 & 1.406 & 1.406 & 1.343 & -0.018 & -0.018 & +0.045 \\
\hline & & $C_{17}-C_{16}$ & 1.365 & 1.382 & 1.403 & 1.346 & -0.017 & -0.038 & +0.019 \\
\hline & & $C_{18}-C_{17}$ & 1.385 & -1.408 & 1.427 & 1.357 & -0.023 & -0.042 & +0.028 \\
\hline & & $C_{19}-C_{18}$ & 1.392 & 1.405 & 1.410 & 1.353 & -0.013 & -0.018 & +0.039 \\
\hline
\end{tabular}

*Italic indicates difference of variation competed among AM1, MM2 and B3LYP Calculations 
Fig. 8 Atom-numbering scheme in 1 used in the document

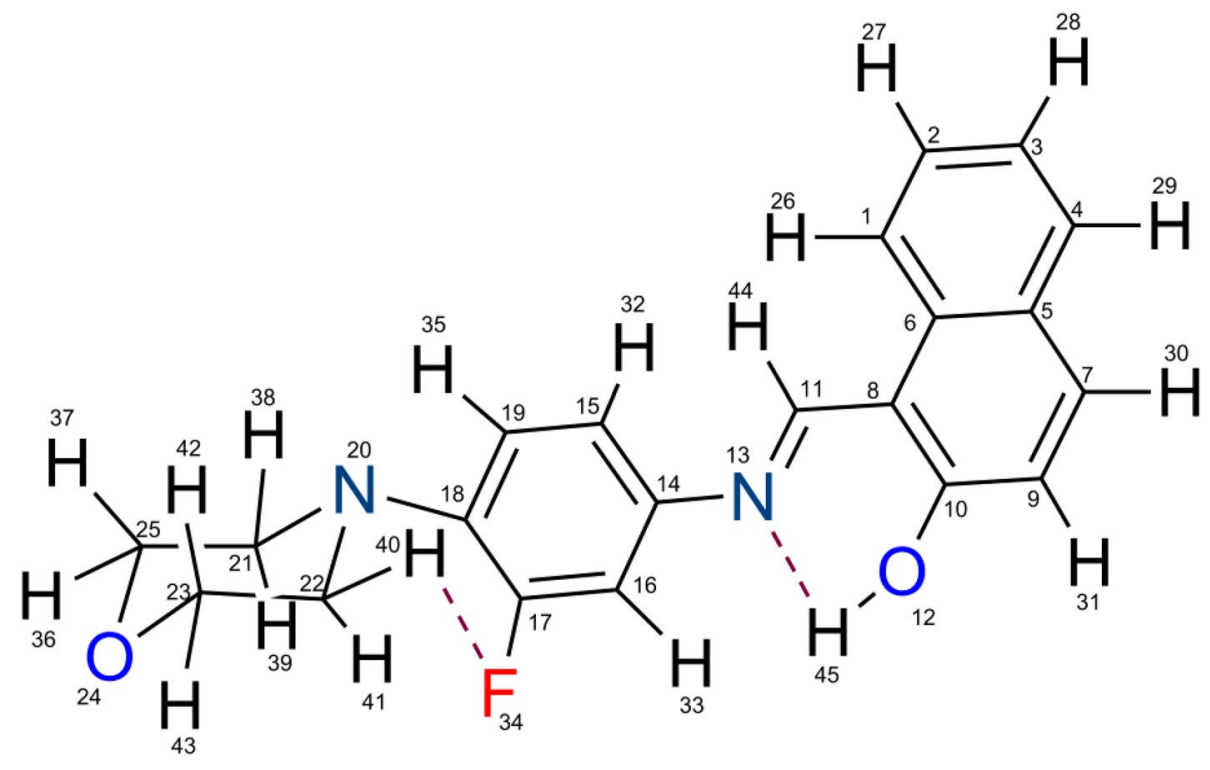

\subsection{Comparison of the X-Ray data with computational data}

The Schiff base, $\mathbf{1}$, is the combination of naphthalene, benzene and morpholine moieties. Ionization potential $(\mathrm{I})$, electron affinity (A), chemical potential $(\mu)$, chemical hardness ( $\eta)$, global softness $(S)$ and electronegativity $(\chi)$ of Schiff base, 1, are calculated from AM1 and DFT/B3LYP method and the same are incorporated in Table 2. It is found that $\mathrm{N}_{20}$ of morpholine has more electron density than $\mathrm{N}_{13}$ atom of the imine as $\mathrm{O}_{24}$ of morpholine has more than naphthenic $\mathrm{O}_{12}$ atom.

The bond lengths (in $\AA$ ) are found to vary slightly in the gaseous state. It is observed that $\sigma \mathrm{H}-\mathrm{C}\left(\mathrm{sp}^{2}\right)$ of aromatic rings is increased by about $0.170 \AA$ in the gaseous state. $\sigma \mathrm{H}-\mathrm{C}\left(\mathrm{sp}^{2}\right)$ of alkenyl is increased by about $0.185 \AA$. $\sigma \mathrm{H}-\mathrm{C}\left(\mathrm{sp}^{3}\right)$ of aliphatic is also increased by $\sim 1.55 \AA$. The other bonds, such as, $\sigma \mathrm{H}-\mathrm{O}\left(\mathrm{sp}^{3}\right), \sigma \mathrm{N}\left(\mathrm{sp}^{3}\right)-\mathrm{C}\left(\mathrm{sp}^{2}\right)$ and $\sigma \mathrm{C}\left(\mathrm{sp}^{2}\right)-\mathrm{O}\left(\mathrm{sp}^{3}\right)$ are noted to have increased their lengths by $\sim 0.148, \sim 0.007, \sim 0.060$ and $\sim 0.017 \AA$, respectively whereas $\sigma \mathrm{F}-\mathrm{C}\left(\mathrm{sp}^{2}\right)$ is decreased by $\sim 0.003 \AA$. The variation of bond lengths as evaluated by computational methods on a gaseous molecule of $\mathbf{1} \mathrm{Vis}$ a Vis the corresponding values for various bonds obtained from the XRD for $\mathbf{1}$ in its solid state are presented in Table 3. The increase in bond length in gaseous state suggests a possible zone of steric strain in the solid state and a decrease in any bond length, a location of intermolecular interaction in the solid state.

The drift in bond angles over several atomic strings is shown in Table 4. Closer the angle computed to the value obtained from XRD, less is the strain experienced by the respective atomic string.

Bond angle $\left(^{\circ}\right)$ at $\mathrm{C}-\mathrm{sp}^{2}$ is observed to vary from -6.7 ${ }^{\circ}$ to $+2.47^{\circ}$ due to angle strain or aromatic strain in the gaseous state. Bond angle $\left(^{\circ}\right)$ at $\mathrm{C}-\mathrm{sp}^{3}$ is found vary from $-4.94^{\circ}$ to $+5.03^{\circ}$. The bond angle at $\mathrm{N}-\mathrm{sp}^{2}$ is decreased (by $\sim 2.66^{\circ}$ ) and that at $\mathrm{N}-\mathrm{sp}^{3}$ is increased (by $\sim 2.25^{\circ}$ ) whereas the bond angle at $\mathrm{O}-\mathrm{sp}^{3}$ is increased by $+2.30^{\circ}$ in the case of morpholine and decreased by $-1.48^{\circ}$ in the case of aromatic $\mathrm{H}-\mathrm{O}-\mathrm{C}$.

The conformational changes as seen from the variation through several dihedral angles over some selected atomic strings are shown in Table 5. Many of the dihedral angles obtained from XRD are inconsistent under one computational method or the other. For example, the dihedral angles of $C_{5} C_{4} C_{3} C_{2}$ and $C_{10} C_{8} C_{6} C_{5}$ are changed from - sc to + sc conformation under AM1 method. The + ac of $\mathrm{C}_{9} \mathrm{C}_{7} \mathrm{C}_{5} \mathrm{C}_{4}$ and $\mathrm{O}_{12} \mathrm{C}_{10} \mathrm{C}_{8} \mathrm{C}_{6}$ change to - ac under DFT. Similarly, the + sc of $C_{18} C_{17} C_{16} C_{14}$ changes to $-s c$ under MM2 method. The - ac of $C_{17} C_{16} C_{14} N_{13}$ change to $+a c$ under all the three computational platforms. The trends of other methods with respect to the empirical data can be seen in Table 5. In near all cases of molecular structural parameters, it is evident from Table 3 through Table 5 that the values obtained from the DFT/B3LYP method appear to be in better agreement with the experimental data than those from the other two platforms, viz., AM1 and MM2.

The geometric data obtained from experimental XRD diffraction studies and molecular modelling studies are collected in Table 3 for comparison.

\section{Conclusions}

A novel Schiff's base, (E)-1-(((3-fluoro-4-morpholinophenyl)imino)methyl) naphthalene-2-ol (1) was synthesized and characterized by UV-Visible, IR, Mass, ${ }^{1} \mathrm{H}-\mathrm{NMR}$ and ${ }^{13} \mathrm{C}$-NMR spectroscopic techniques and by single 
Table 4 Comparative list of selected bond angles $\left(^{\circ}\right)$ between experimental XRD and calculated AM1, MM2 and B3LYP studies

\begin{tabular}{|c|c|c|c|c|c|c|c|c|}
\hline \multirow[t]{2}{*}{ Central atom } & \multirow[t]{2}{*}{ Atomic String (Fig. 8) } & \multirow[t]{2}{*}{$\mathrm{XRD}$} & \multirow[t]{2}{*}{ B3LYP } & \multirow[t]{2}{*}{ AM1 } & \multirow[t]{2}{*}{ MM2 } & \multicolumn{3}{|l|}{ Variation, $\delta,\left({ }^{\circ}\right)^{*}$} \\
\hline & & & & & & $\Delta(\mathrm{XRD}-\mathrm{B} 3 \mathrm{LYP})$ & $\Delta(\mathrm{XRD}-\mathrm{AM} 1)$ & $\Delta(\mathrm{XRD}-\mathrm{MM} 2)$ \\
\hline \multirow[t]{28}{*}{$\mathrm{Csp}^{2}$} & $\mathrm{C}_{3} \mathrm{C}_{2} \mathrm{C}_{1}$ & 120.80 & 120.92 & 120.70 & 120.11 & -0.12 & +0.10 & +0.69 \\
\hline & $\mathrm{C}_{4} \mathrm{C}_{3} \mathrm{C}_{2}$ & 119.30 & 119.16 & 119.82 & 118.34 & +0.14 & -0.52 & +0.96 \\
\hline & $\mathrm{C}_{5} \mathrm{C}_{4} \mathrm{C}_{3}$ & 121.30 & 121.15 & 120.68 & 120.94 & +0.15 & +0.62 & +0.36 \\
\hline & $\mathrm{C}_{6} \mathrm{C}_{5} \mathrm{C}_{4}$ & 120.30 & 120.08 & 119.74 & 122.23 & +0.22 & +0.56 & -1.93 \\
\hline & $\mathrm{C}_{7} \mathrm{C}_{5} \mathrm{C}_{4}$ & 121.00 & 120.69 & 120.31 & 117.65 & +0.31 & +0.69 & +3.35 \\
\hline & $\mathrm{C}_{8} \mathrm{C}_{6} \mathrm{C}_{5}$ & 119.30 & 119.13 & 119.05 & 120.25 & +0.17 & +0.25 & -0.95 \\
\hline & $\mathrm{C}_{9} \mathrm{C}_{7} \mathrm{C}_{5}$ & 122.00 & 121.59 & 120.82 & 119.47 & +1.41 & +1.18 & +2.53 \\
\hline & $\mathrm{C}_{10} \mathrm{C}_{8} \mathrm{C}_{6}$ & 119.54 & 118.97 & 119.12 & 118.90 & +0.57 & +0.42 & +0.64 \\
\hline & $\mathrm{C}_{11} \mathrm{C}_{8} \mathrm{C}_{6}$ & 121.30 & 121.58 & 123.77 & 121.78 & -0.28 & -2.47 & -0.48 \\
\hline & $\mathrm{O}_{12} \mathrm{C}_{10} \mathrm{C}_{8}$ & 123.50 & 122.76 & 117.43 & 124.75 & +0.74 & +6.07 & -1.25 \\
\hline & $\mathrm{C}_{15} \mathrm{C}_{14} \mathrm{~N}_{13}$ & 116.20 & 118.00 & 118.02 & 116.01 & -1.80 & -1.82 & +0.19 \\
\hline & $\mathrm{C}_{16} \mathrm{C}_{14} \mathrm{~N}_{13}$ & 125.10 & 123.91 & 123.79 & 128.88 & +1.19 & +1.31 & -3.78 \\
\hline & $C_{17} C_{16} C_{14}$ & 118.80 & 119.66 & 121.02 & 122.98 & -0.86 & -2.22 & -4.18 \\
\hline & $\mathrm{C}_{18} \mathrm{C}_{17} \mathrm{C}_{16}$ & 124.50 & 123.58 & 121.02 & 122.57 & +0.92 & +3.48 & +1.93 \\
\hline & $\mathrm{C}_{19} \mathrm{C}_{18} \mathrm{C}_{17}$ & 115.50 & 115.66 & 116.72 & 113.44 & -0.16 & -1.22 & +2.06 \\
\hline & $\mathrm{N}_{20} \mathrm{C}_{18} \mathrm{C}_{17}$ & 120.70 & 119.33 & 119.66 & 125.00 & +1.37 & +1.04 & -4.30 \\
\hline & $\mathrm{H}_{26} \mathrm{C}_{1} \mathrm{C}_{2}$ & 119.00 & 118.11 & 119.38 & 112.86 & -0.89 & -0.38 & +6.14 \\
\hline & $\mathrm{H}_{27} \mathrm{C}_{2} \mathrm{C}_{3}$ & 119.60 & 119.72 & 119.03 & 119.39 & -0.12 & +0.57 & +0.21 \\
\hline & $\mathrm{H}_{28} \mathrm{C}_{3} \mathrm{C}_{2}$ & 120.40 & 120.22 & 119.31 & 120.72 & +0.18 & +1.09 & -0.32 \\
\hline & $\mathrm{H}_{29} \mathrm{C}_{4} \mathrm{C}_{3}$ & 119.30 & 120.49 & 120.82 & 117.64 & -1.19 & -1.52 & +1.66 \\
\hline & $\mathrm{H}_{30} \mathrm{C}_{7} \mathrm{C}_{5}$ & 119.00 & 118.43 & 118.68 & 121.98 & +0.57 & +0.32 & -2.98 \\
\hline & $\mathrm{H}_{31} \mathrm{C}_{9} \mathrm{C}_{7}$ & 119.70 & 122.08 & 121.29 & 118.74 & -2.38 & -1.59 & +0.96 \\
\hline & $\mathrm{H}_{32} \mathrm{C}_{15} \mathrm{C}_{14}$ & 119.50 & 118.67 & 119.88 & 119.86 & +0.83 & -0.38 & -0.36 \\
\hline & $\mathrm{H}_{33} \mathrm{C}_{16} \mathrm{C}_{14}$ & 120.60 & 122.07 & 120.85 & 121.12 & -1.47 & -0.25 & -0.52 \\
\hline & $\mathrm{F}_{34} \mathrm{C}_{17} \mathrm{C}_{16}$ & 117.40 & 117.82 & 117.90 & 113.92 & -0.42 & -0.50 & +3.48 \\
\hline & $\mathrm{H}_{35} \mathrm{C}_{19} \mathrm{C}_{18}$ & 119.30 & 119.16 & 119.76 & 122.86 & +0.14 & -0.46 & -3.56 \\
\hline & $\mathrm{H}_{44} \mathrm{C}_{11} \mathrm{C}_{8}$ & 119.20 & 117.84 & 112.49 & 119.04 & +1.36 & +6.71 & +0.16 \\
\hline & $\mathrm{N}_{13} \mathrm{C}_{11} \mathrm{C}_{8}$ & 121.50 & 122.52 & 123.39 & 127.61 & -1.02 & -1.89 & -6.11 \\
\hline \multirow[t]{10}{*}{$\mathrm{Csp}^{3}$} & $\mathrm{C}_{23} \mathrm{C}_{22} \mathrm{~N}_{20}$ & 109.50 & 111.40 & 114.53 & 114.83 & -1.9 & -5.03 & -5.33 \\
\hline & $\mathrm{O}_{24} \mathrm{C}_{23} \mathrm{C}_{22}$ & 111.70 & 110.23 & 111.52 & 111.15 & +1.47 & +0.18 & +0.55 \\
\hline & $\mathrm{H}_{36} \mathrm{C}_{25} \mathrm{O}_{24}$ & 109.20 & 110.38 & 104.26 & 107.84 & -1.18 & +4.94 & +1.36 \\
\hline & $\mathrm{H}_{37} \mathrm{C}_{25} \mathrm{O}_{24}$ & 109.20 & 105.24 & 109.31 & 109.32 & +3.96 & -0.11 & -0.12 \\
\hline & $\mathrm{H}_{38} \mathrm{C}_{21} \mathrm{~N}_{20}$ & 109.70 & 107.28 & 105.43 & 108.33 & +2.42 & +4.27 & +1.37 \\
\hline & $\mathrm{H}_{39} \mathrm{C}_{21} \mathrm{~N}_{20}$ & 109.70 & 108.95 & 110.31 & 111.45 & +0.75 & -0.61 & -1.75 \\
\hline & $\mathrm{H}_{40} \mathrm{C}_{22} \mathrm{~N}_{20}$ & 109.80 & 110.26 & 109.97 & 110.99 & -0.46 & -0.17 & -1.19 \\
\hline & $\mathrm{H}_{41} \mathrm{C}_{22} \mathrm{~N}_{20}$ & 109.80 & 107.28 & 106.01 & 108.36 & +2.52 & +3.79 & +1.44 \\
\hline & $\mathrm{H}_{42} \mathrm{C}_{23} \mathrm{C}_{22}$ & 109.80 & 108.23 & 110.30 & 111.59 & +1.57 & -0.50 & -1.79 \\
\hline & $\mathrm{H}_{43} \mathrm{C}_{23} \mathrm{C}_{22}$ & 109.80 & 111.09 & 111.09 & 110.55 & -1.29 & -1.29 & -0.75 \\
\hline $\mathrm{Nsp}^{2}$ & $\mathrm{C}_{14} \mathrm{~N}_{13} \mathrm{C}_{11}$ & 123.80 & 121.86 & 121.14 & 128.77 & +1.94 & +2.66 & -4.97 \\
\hline \multirow[t]{2}{*}{$\mathrm{Nsp}^{3}$} & $\mathrm{C}_{21} \mathrm{~N}_{20} \mathrm{C}_{18}$ & 117.16 & 119.35 & 117.39 & 119.75 & -2.19 & -0.23 & -2.59 \\
\hline & $\mathrm{C}_{22} \mathrm{~N}_{20} \mathrm{C}_{18}$ & 114.71 & 117.11 & 115.74 & 120.57 & -2.40 & -1.03 & -5.86 \\
\hline \multirow[t]{2}{*}{ Osp ${ }^{3}$} & $\mathrm{C}_{25} \mathrm{O}_{24} \mathrm{C}_{23}$ & 110.40 & 111.97 & 112.70 & 110.21 & -1.57 & -2.30 & +0.19 \\
\hline & $\mathrm{H}_{45} \mathrm{O}_{12} \mathrm{C}_{10}$ & 109.50 & 107.11 & 108.02 & 112.39 & +2.39 & +1.48 & -2.89 \\
\hline
\end{tabular}

*Italic indicates difference of variation competed between AM1, MM2 and B3LYP Calculations

crystal XRD studies. There is a good correlation of both ${ }^{1} \mathrm{H}$ and ${ }^{13} \mathrm{C}$ NMR data with the expected chemical shift values of various $\mathrm{H}$ and $\mathrm{C}$ atoms respectively while they corroborate with the intra-molecular $\mathrm{H}$-bonding. The comparison of experimental XRD crystal data of 1 with those evaluated by computational analysis from 
Table 5 Comparative list of selected Dihedral angle $\left(^{\circ}\right)$ of Schiff base, from experimental XRD and AM1, MM2, B3LYP calculations

\begin{tabular}{|c|c|c|c|c|c|c|c|c|}
\hline \multirow[t]{2}{*}{ Dihedral angle $\left(^{\circ}\right)$} & \multicolumn{2}{|l|}{ XRD } & \multicolumn{2}{|l|}{ B3LYP } & \multicolumn{2}{|l|}{ AM1 } & \multicolumn{2}{|l|}{ MM2 } \\
\hline & Angle & $(*)$ & Angle & $(*)$ & Angle & $(*)$ & Angle & $(*)$ \\
\hline $\mathrm{C}_{4} \mathrm{C}_{3} \mathrm{C}_{2} \mathrm{C}_{1}$ & +1.1 & $+s c$ & +0.08 & $+s c$ & -0.48 & $-s c$ & -0.006 & $-s c$ \\
\hline $\mathrm{C}_{5} \mathrm{C}_{4} \mathrm{C}_{3} \mathrm{C}_{2}$ & -0.2 & $-s c$ & -0.05 & $-s c$ & +0.36 & $+s c$ & -0.005 & $-s c$ \\
\hline $\mathrm{C}_{6} \mathrm{C}_{5} \mathrm{C}_{4} \mathrm{C}_{3}$ & -0.7 & $-s c$ & -0.08 & $-s c$ & +0.67 & $-s c$ & +0.04 & $+s c$ \\
\hline$C_{7} C_{5} C_{4} C_{3}$ & +178.8 & $+a c$ & +179.81 & $+a c$ & -179.12 & $+a c$ & +179.95 & $+a c$ \\
\hline $\mathrm{C}_{8} \mathrm{C}_{6} \mathrm{C}_{5} \mathrm{C}_{4}$ & -179.5 & $-a c$ & -179.81 & $-a c$ & +179.53 & $+a c$ & -179.90 & $-a c$ \\
\hline $\mathrm{C}_{9} \mathrm{C}_{7} \mathrm{C}_{5} \mathrm{C}_{4}$ & +180.0 & $+a c$ & -179.78 & $-a c$ & +179.20 & $+a c$ & -179.79 & $-a c$ \\
\hline $\mathrm{C}_{10} \mathrm{C}_{8} \mathrm{C}_{6} \mathrm{C}_{5}$ & -0.6 & $-s c$ & -0.57 & $-s c$ & +1.79 & $+s c$ & -0.05 & $-s c$ \\
\hline$C_{11} C_{8} C_{6} C_{5}$ & +177.4 & $+a c$ & +179.26 & $+a c$ & -179.04 & $-a c$ & +179.50 & $+a c$ \\
\hline $\mathrm{O}_{12} \mathrm{C}_{10} \mathrm{C}_{8} \mathrm{C}_{6}$ & +178.8 & $+a c$ & -179.43 & $-a c$ & +178.45 & $+a c$ & -178.26 & $-a c$ \\
\hline $\mathrm{O}_{12} \mathrm{C}_{10} \mathrm{C}_{8} \mathrm{C}_{11}$ & - & - & +0.72 & $+s c$ & - & - & +2.18 & $+s c$ \\
\hline $\mathrm{C}_{8} \mathrm{C}_{7} \mathrm{C}_{11} \mathrm{~N}_{13}$ & - & - & +1.14 & $+s c$ & - & - & +1.17 & $+s c$ \\
\hline $\mathrm{N}_{13} \mathrm{C}_{11} \mathrm{C}_{8} \mathrm{C}_{6}$ & -178.4 & $-a c$ & +179.02 & $+a c$ & +49.29 & $+s p$ & -178.38 & $-a c$ \\
\hline $\mathrm{C}_{14} \mathrm{~N}_{13} \mathrm{C}_{11} \mathrm{C}_{8}$ & +178.9 & $+a c$ & +177.20 & $+a c$ & +179.02 & $+a c$ & -179.73 & $-a c$ \\
\hline $\mathrm{C}_{15} \mathrm{C}_{14} \mathrm{~N}_{13} \mathrm{C}_{11}$ & -171.5 & $-a c$ & +153.46 & $+a c$ & -150.99 & $-a c$ & -179.88 & $-a c$ \\
\hline $\mathrm{C}_{16} \mathrm{C}_{14} \mathrm{~N}_{13} \mathrm{C}_{11}$ & +9.6 & $+s c$ & -28.58 & $-s c$ & +32.06 & $+s p$ & -0.15 & $-s c$ \\
\hline $\mathrm{C}_{17} \mathrm{C}_{16} \mathrm{C}_{14} \mathrm{~N}_{13}$ & -179.3 & $-a c$ & 179.63 & $+a c$ & +176.37 & $+a c$ & +179.99 & $+a c$ \\
\hline $\mathrm{C}_{18} \mathrm{C}_{17} \mathrm{C}_{16} \mathrm{C}_{14}$ & +0.0 & $+s c$ & +1.51 & $+s c$ & +0.76 & $+s c$ & -0.15 & $-s c$ \\
\hline $\mathrm{F}_{34} \mathrm{C}_{17} \mathrm{C}_{16} \mathrm{C}_{14}$ & -179.3 & $-a c$ & -179.51 & $-a c$ & -179.44 & $-a c$ & +179.45 & $+a c$ \\
\hline $\mathrm{F}_{34} \mathrm{C}_{17} \mathrm{C}_{18} \mathrm{~N}_{20}$ & - & - & +3.12 & $+s c$ & - & - & +0.30 & $+s c$ \\
\hline$C_{19} C_{18} C_{17} C_{16}$ & -1.9 & $-s c$ & +0.27 & $+s c$ & -0.01 & $-s c$ & +0.74 & $+s c$ \\
\hline $\mathrm{N}_{20} \mathrm{C}_{18} \mathrm{C}_{17} \mathrm{C}_{16}$ & -179.4 & $-a c$ & -177.91 & $-a c$ & -175.9 & $-a c$ & +180.00 & $+a c$ \\
\hline $\mathrm{C}_{17} \mathrm{C}_{18} \mathrm{~N}_{20} \mathrm{C}_{21}$ & - & - & +1.86 & $+s c$ & - & - & +2.17 & $+s C$ \\
\hline $\mathrm{C}_{21} \mathrm{~N}_{20} \mathrm{C}_{18} \mathrm{C}_{17}$ & +164.3 & $+a c$ & +158.90 & $+a c$ & +159.81 & $+a c$ & -176.98 & $-a c$ \\
\hline $\mathrm{C}_{22} \mathrm{~N}_{20} \mathrm{C}_{18} \mathrm{C}_{17}$ & -64.3 & $-s p$ & -64.65 & $-s p$ & -65.35 & $-s p$ & -1.72 & $-a c$ \\
\hline $\mathrm{C}_{23} \mathrm{C}_{22} \mathrm{~N}_{20} \mathrm{C}_{18}$ & +169.2 & $+a c$ & -76.35 & $-s p$ & -91.61 & $-a p$ & +174.25 & $+a c$ \\
\hline $\mathrm{O}_{24} \mathrm{C}_{23} \mathrm{C}_{22} \mathrm{~N}_{20}$ & +57.9 & $+s p$ & -23.50 & $-s c$ & -51.53 & $-s p$ & +36.74 & $+s p$ \\
\hline $\mathrm{C}_{25} \mathrm{O}_{24} \mathrm{C}_{23} \mathrm{C}_{22}$ & -58.2 & $-s p$ & -40.65 & $-s p$ & +55.56 & $+s p$ & -66.91 & $-s p$ \\
\hline
\end{tabular}

${ }^{*}$ Conformational analyses using prefixes $a=$ anti, $s=$ syn, $p=$ peri-planar, $c=$ clinal $\left(0 \pm 30^{\circ} \& 180 \pm 30^{\circ}\right)$ and + and - signs fully optimized semi empirical AM1 calculations by MOPAC, MM2 and DFT/B3LYP calculations is presented and discussed. There is an excellent agreement of the computationally evaluated data with the empirical data obtained by single crystal XRD data. Only in the locations of the heteroatoms on the morpholine ring and at $-\mathrm{C}=\mathrm{NH}, \mathrm{F}-\mathrm{C}-$ and $\mathrm{H}-\mathrm{O}-\mathrm{C}-$ moieties are slight deviations observed. These are justified on the basis of the fact that XRD data is a bulk data for a crystallised molecule with a variety of intermolecular interactions whereas the AM1 and MM2 calculations are done on a single free molecule in its gaseous state. These investigations suggest a potential scope for DFT/B3LYP, AM1 and MM2 calculations to predict to a reasonable confidence the molecular properties of some medium sized known (reported) molecules that could not be crystallised, good enough for XRD studies, and those of simulated new molecules that may not yet be synthesized or cannot be synthesized.
Acknowledgements The authors thank Dr. Shibu M Eapen, Scientistin-charge Saif Stic, Kochi University, Kerala, for providing Single Crystal XRD (SCXRD). They also acknowledge with thanks Dr. Ravinder Pawar, Department of Chemistry, NIT Warangal for supplying the DFT/B3LYP calculations on 1. TDR is thankful to the Director, NIT Warangal for the financial assistance through the Institute Senior Research Fellowship (SRF).

\section{Compliance with ethical standard}

Conflict of interest There are no conflicts to declare.

\section{References}

1. Kafi AL, Shirmohammadzadeh L (2017) Synthesis of Co(II) and $\mathrm{Cr}$ (III) salicylidenic Schiff base complexes derived from thiourea as precursors for nano-sized $\mathrm{CO}_{3} \mathrm{O}_{4}$ and $\mathrm{Cr}_{2} \mathrm{O}_{3}$ and their catalytic Antibacterial Properties. J Nanostruct Chem 7:179 
2. Emad $Y$, Ahmed $M$, Khulood AS, Nadia S, Jumat S, Bashar A (2017) Metal complexes of Schiff base: preparation, characterization and antibacterial activity. Arab J Chem 10:s1639

3. Das P, Linert W (2016) Schiff base-derived homogeneous and heterogeneous palladium catalysts for the suzuki-miyaura reaction. Coord Chem Rev 311:1

4. Bushra I, Kanwal J, Muhammad SUK, Zareen A, Bushra M, Vickie M (2017) Synthesis, characterization and biological assay of salicylaldehyde Schiff base Cu(II) complexes and their precursors. J Mol Struct 1155:337

5. Niloofar M, Mahdi B, Hadi AR, Giuseppe B, Bahram G (2016) Unique examples of copper(II)/sodium(I) and nickel(II)/sodium(I) Schiff base complexes with bridging bis-bidentate salen type ligand: synthesis, crystal structures and antibacterial studies. Inorg Chim Acta 445:124

6. Abdur R, Afzal S, Abdul AK, Aamir HS, Rashda A, Irfan ZQ, Saqib A (2017) Synthesis, pH- dependent photometric and electrochemical investigation, redox mechanism and biological applications of novel Schiff base and its metallic derivatives. Spectrochim Acta A 176:155

7. El-Shahawi MS, Al-Jahdali MS, Bashammakh AS, AI-Sibaai AA, Nassef HM (2013) Spectroscopic and electrochemical characterization of some Schiff base metal complexes containing benzoin moiety. Spectrochim Acta A Mol Biomol Spectrosc 113C:459

8. Jayaseelan P, Akila E, Usha Rani M, Rajavel R (2016) Synthesis, spectral characterization, electrochemical, anti-microbial, DNA binding and cleavage studies of new binuclear Schiff base metal(II) complexes derived from o-hydroxyacetophenone. J Saudi Chem Soc 20:625

9. Sapana K, Ghanshyam SC (2014) New cellulose-lysine Schiffbase-based sensor-adsorbent for mercury ions. ACS Appl Mater Interfaces 6:5908

10. Hamilton DE, Drago RS, Zombeck A (1987) Mechanistics studies on the cobalt (11) Schiff base catalyzed oxidation of olefins by $\mathrm{O}_{2}$. J Am Chem Soc 109:374

11. Aliasghar J, Pouria $S$, Hashem $S$, Mahdi $A$, Véronique $S$, Christine $L$, Jean B (2015) Synthesis of novel mono- and bis-Schiff bases of morpholinederivatives and the investigation of their antimalarialand antiproliferative activities. Med Chem Res 24:4105

12. Dhahagani K, Mathan Kumar S, Chakkaravarthi G, Anitha K, Rajesh J, Ramu A, Rajagopal G (2014) Synthesis and spectral characterization of Schiff Base complexes of Cu(II), Co(II), Zn(II) and VO(IV) Containing 4-(4-Aminophenyl)morpholine derivatives: antimicrobial evaluation and anticancer studies. Spectrochim Acta A Mol Biomol Spectrosc 117:87

13. Alexios NM, Angeliki PK (2019) Optimizing the pharmacological profile of new bifunctional antihyperlipidemic/antioxidant morpholine derivatives. ACS Med Chem Lett 10:98

14. Michael CC, Eleni AR, Panos NK (2000) Hypocholesterolemic and hypolipidemic activity of some novel morpholine derivatives with antioxidant activity. J Med Chem 43:609

15. Sankarganesh M, Raja JD, Revathi N, Vijay Solomon R, Senthil Kumar R (2019) Gold(III) complex from pyrimidine and morpholine analogue Schiff base ligand: synthesis, characterization, DFT, TDDFT, catalytic, anticancer, molecular modeling with DNA and BSA and DNA binding studies. J Mol Liq 294:111655

16. El-Samanody ESA, Emam SM, Emara EM (2017) Synthesis, characterization, molecular modeling and biological activity of metal complexes derived from (E)- $N^{\prime}$-(Furan-2-ylmethylene) morpholine-4-carbothiohydrazide. J Mol Struct 1146:868

17. Kumar R, Vulichi S, Suman K (2016) Emphasizing morpholine and its derivatives (maid): typical candidate of pharmaceutical importance. Int J Chem Sci 14(3):1777

18. Farghaly T, Abu AA, El-Ghamry H, Shaaban M (2020) Synthesis and DNA binding of novel bioactive thiazole derivatives pendent to $\underline{N}$-phenylmorpholine moiety. Bioorg Chem 102:104103

19. Kourounakis AP, Xanthopoulos D, Tzara A (2020) Morpholine as a privileged structure: a review on the medicinal chemistry and pharmacological activity of morpholine containing bioactive molecules. Med Res Rev 40(2):709

20. Tamami B, Ghasemi S (2015) Catalytic activity of Schiff-base transition metal complexes supported on crosslinked polyacrylamides for hydrogen peroxide decomposition. J Organomet Chem 794:311

21. Logu L, Raja K, Rajagopal G, Deivanayagam E (2014) Schiff base complexes of rare earth metal ions: synthesis, characterization and catalytic activity for the oxidation of aniline and substituted anilines. J Organomet Chem 753:72

22. Arora K, Burman K (2005) Theoretical semi-empirical AM1 studies of Schiff bases. J Saudi Chem Soc 9(2):297

23. Abdel-Aziz AA-M, Al-Omar MA, El-Azaab AS, Kunieda T (2010) conformational preferences of sterically congested 2-imidazolidinone using $\mathrm{X}$-ray analysis and computational studies. Part 1: trans-1-Acetyl-4,5-di-tert-butyl-2-imidazolidinone. J Mol Struct 969(1-3):145

24. Burley JC, Gilmour R, Prior TJ, Day GM (2008) Structural diversity in imidazolidinone organocatalysts: a synchrotron and computational study. Acta Crystallographica C C64:010

25. Christensen AS, Kubar T, Cui Q, Elstner M (2016) Semiempirical quantum mechanical methods for noncovalent interactions for chemical and biochemical applications. Chem Rev 116(9):5301

26. Bilge S, Kilic Z, Hayvali Z, Hokelek T, Safran S (2019) Intramolecular hydrogen bonding and tautomerism in Schiff bases: Part VI. syntheses and structural investigation of salicylaldimine and naphthaldimine derivatives. J. Chem. Sci. 121:989

27. Umezawa Y, Tsuboyama S, Takahashi H, Uzawa J, Nishio M (1999) $\mathrm{CH} / \pi$ interaction in the conformation of organic compounds: a database study. Tetrahedron 55(33):10047

28. Ueda $H$, Onishi $H$, Nagi $T$ (1986) Structure of $p$-Aminobenzoic Acidi-1,3-dimethyl-2-imidazolidinone (1/1). Acta Crystallogr $C$ C42:462

29. Kapon M, Reisner GM (1985) Structure of 2-Imidazolidinone Hemihydrate. Acta Crystallogr C C45:780

30. Peeters OM, Blaton NM, De Ranter CJ (1984) Structure of I-(5-Nitro-1,3-thiazol-2-yl)-2-imidazolidinone (Niridazole), $\mathrm{C}_{6} \mathrm{H}_{6} \mathrm{~N}_{4} \mathrm{O}_{3} \mathrm{~S}$. Acta Crystallogr C C40:1748

31. Abd El-Kareem M, Rabbih M, Selim E, Elsherbiny EA, El-Khateeb A (2016) Application of GC/EIMS in combination with semiempirical calculations for identification and investigation of some volatile components in basil essential oil. Int J Anal Mass Spectrom 4:14

32. Temitope EO, Isaiah AA, Bernardus V, Gareth MW (2015) Crystal structures, spectroscopic and theoretical study of novel schiff bases of 2-(Methylthiomethyl)anilines. Spectrochim Acta A 139:385

33. Klyne W, Prelog V (1960) Description of steric relationships across single bonds. Experientia 16:521

34. Stewart JJP (1989) Optimization of parameters for semiempirical methods I. method. J Comput Chem 10(2):209

35. Fletcher R, Powell MJD (1963) A rapidly convergent descent method for minimization. Comput J 6:163

36. Davidson WJ (1968) Variance algorithm for minimization. Comput J 10:406

Publisher's Note Springer Nature remains neutral with regard to jurisdictional claims in published maps and institutional affiliations. 